\title{
Simbolinis Aldonos Gustas kraštovaizdis poezijoje ir tapyboje
}

\author{
AURELIJA MYKOLAITYTÉ \\ Lietuvos kultūros tyrimų institutas, Saltoniškių g. 58, LT-08105 Vilnius \\ El. paštas: a.mykolaityte@hmf.vdu.lt
}

\begin{abstract}
Straipsnyje gilinamasi ị lietuvių kilmès poetès ir dailininkès Aldonos Gustas (g. 1932) kūrybą, kurioje labai svarbią vietą užima Lietuvos kraštovaizdis, vaikystès atsiminimai. Ši patirtis buvo atkurta jau gyvenant Vokietijoje, Vakarų Berlyne: vaizduotè atgaivino tai, kas būta pojūčiuose, ir suteikè impulsų savitai meninei raiškai.
\end{abstract}

Raktažodžiai: kraštovaizdis, poezija, tapyba, atmintis, vaizduotė

\section{IVADAS}

Aldona Gustas išgarsèjo ne Lietuvoje, o Vokietijoje - šioje šalyje pasirodė visi jos poezijos rinkiniai, čia ji pati organizavo poetų dailininkų parodas ir jose dalyvavo su savo darbais. Vis dèlto gimtinè paliko savo ženklus tiek žodžiuose, tiek spalvose ir linijų kontūruose. Pati rašytoja pripažįsta, kad poezijai impulsų davẻ senosios lietuvių dainos: „Ir aš, be abejo, susijusi su šia sena tradicija. Kiek siekia atmintis, man rodos, kad vaikysteje aš daugiau dainavau negu kalbejjau“ [8, 102-103]. Tapybą taip pat sieja su Lietuva: „Mano paveikslų turinys, jų keisti simboliai - atgarsis tų dienų, kai pėsčia ar su dviračiu keliaudavau po Lietuvos miškus" $[8,104]$. Šiame straipsnyje sieksiu išaiškinti, kas poetei-dailininkei yra tas pasaulis, kurị ji paliko būdama devynerių, 1941 m., ir kur galejo sugrịžti tik atsiminimuose.

Lig šiol Lietuvoje A. Gustas kūrybos, tiek poezijos, tiek tapybos, aptarčių rastume gana mažai. Pirmiausia minètini žurnaluose publikuoti išeivių straipsniai - tai Juozo Girniaus „Aldona Gustaitè. Vokiečių poetė lietuvaitė“ (Aidai, 1969), Audronès B. Willeke „Voratinklių narveliai: Aldonos Gustas poezija“ (Lituanus, 1981), R. E. Maziliausko „Panas lietuviškose samanose. Aldona Gustas ir jos kūryba“ (Septintoji Pradalgè, 1970). Visi paminèti tyrèjai labiausiai pabrèžia šios poetès lietuvišką kilmę ir lietuviškus motyvus. A. B. Willeke akcentuoja A. Gustas kitoniškumą vokiškoje aplinkoje ir jai būdingą intuityvumą, glaustumą, paprastumą [11], R. E. Maziliauskas lygina su išeivių „nužemintųjų“ karta, brendusia kitakalbejje aplinkoje, ir išskirtinumą atranda vokiškai lietuviškame skambume [9, 315-316]; J. Girnius bene labiausiai pabrèžia lietuvišką sąmonę, kuri, anot pačios poetès, yra „natūralus pirminis stovis“ [1]. Sovietinejje Lietuvoje šios poetès kūrybos vertimų ir aptarčių èmèsi Vytautas Karalius, kurio palydimasis knygos Briedžiai mano broliai straipsnis „Apsèti lauką eilèraščiais..." buvo bene pirmasis bandymas kalbėti apie šią lietuvių kilmès poetę užsimenant ir apie lietuviškus tapybos motyvus $[8,104]$. Kitiems lietuvių tyrèjams, kurių 
tekstai buvo publikuoti kultūrinèje Lietuvos spaudoje, A. Gustas kūryba reiškẻ kultūrinès atminties klodus: Ona Baliukonytė rašè apie „atsiminimų - sapnų - regejjimų vainiką" [2, 5], Vytautas Kubilius akcentavo „poetinị prarastos žemès mitą“ [7, 181], Sigitas Geda jau nepriklausomos Lietuvos laikais A. Gustas poeziją apibendrino pačiu recenzijos pavadinimu - „Kažkas iš mūsų pramotès“ $[4,14)$. Paskelbtas pluoštas apžvalginių darbų apie paveikslų parodas: Ainès Jacytės, Gabrielès Kuizinaitès, Aušros Vasiliauskienès, Jadvygos Godunavičienès, Neringos Kažukauskaitès ir kt. Deja, nėra nė vienos publikacijos, kurioje būtų siekta aprèpti abi A. Gustas kūrybos sritis: tiek poeziją, tiek tapybą. Šio straipsnio išskirtinumas - analizuoti abu meninès raiškos būdus, gilinantis ị reikšmes, kurias atveria eilèraščiai ir paveikslai, ịvairiapusè poetès-dailininkès kūryba. Tokiam tyrimui pasitelktas fenomenologinis metodas leidžia kalbèti apie gyvenamojo pasaulio patirtis ir jų atspindžius kultūros tekstuose.

\section{KAIP ISIVAIZDUOTI REGIMYBĘ?}

Lietuvei poetei-dailininkei A. Gustas mažai teko gyventi Lietuvoje: gimusi Karceviškių kaime, lietuvių šeimoje, jau vaikysteje atskirta nuo šio krašto Antrojo pasaulinio karo metais, apsigyveno Vakarų Berlyne ir šis miestas tapo jos kūrybos erdve. Ir vis dèlto, nematydama realios Lietuvos, A. Gustas ją atkuria eilèraščiuose ir tapyboje kaip prisiminimą, kuris apibendrina buvusias patirtis. Šiame pasaulyje ji yra mergaite, išgyvenanti savo vaikišką būtị.

Fenomeną, kaip mūsų dvasia yra susijusi su regimybe, yra tyrinejjęs garsus prancūzų fenomenologas Maurice’as Merleau-Ponty, kurio knygos Akis ir dvasia įžvalgos padeda atskleisti A. Gustas pasaulèvaizdžio unikalumą. Pasak filosofo, „<...> regintysis priklauso tam, ką regi, liečiantysis - tam, ką liečia, juntantysis - tam, ką, junta; tad tai [būtis] sau, ipinta tarp daiktų, turinti veidą ir nugarą, praeitị ir ateitị... " [10, 47]. Ypač svarbi tampa pati kūno patirtis, buvimas tam tikroje vietoje, žvilgsnio kryptis ir pan., nes visa, kas mus supa, „sukelia aidą mūsų kūne“ $[10,50]$. M. Merleau-Ponty nurodo, kad tai yra pagrindas antrojo laipsnio regimybei - ikonai, kurios negalima pavadinti nei kalke, nei kopija, nei antriniu daiktu: tai regejjimas iš vidaus, ịsivaizduojama tikrovès tekstūra. Filosofas pabrèžia, kad nèra jokio skirtumo, kaip dailininkas tapo - iš natūros ar ne: „Niekas nesikeičia, jei jis netapo iš natūros: šiaip ar taip, jis tapo, nes matè, nes pasaulis bent kartą išgraviravo jame regimybès šifrus“ $[10,55]$.

A. Gustas kūrybai, tiek poezijai, tiek tapybai, yra būdingas būtent šis regejimas iš vidaus, regimybės šifravimas: rašydama ir kurdama savo paveikslus Lietuvos ji nemate, bet gimtasis kraštas buvo gyvas vaizduoteje. „Gerai atsimenu tam tikrus kelius, tiltus, miškus, senas kapines, pievas, kates, šunis, varles, skruzdes, žibutes etc. Kai, pavyzdžiui, savo eilèraščiuose miniu samanas, tai visada prisimenu Lietuvos mišku samanas, kurias kaip vaikas esu mačiusi. Taip yra ir su nesuskaičiuojamais kitais dalykais, ir tuo būdu per pirmąsias patirtis, pirmuosius pergyvenimus, kuriuos kaip vaikas sutelkiau, mano ryšys su tẻviške yra kiek galint nuoširdus, ir sąmoningai nesistengiant", - prisipažįsta poete išeivių bendruomenei [1].

\section{TAPYBIŠKAS NAMŲ VAIZDINYS}

A. Gustas yra ịsigyvenusi ị savo vaikystès kraštovaizdį: mini artimas vietas, savus žmones, liudija artumą gimtinès gamtai, kuri tebèra aplink ją. Kone visuose eilèraščiuose ryškejja „aš“ perspektyva - maža mergaitè perteikia vaikystès pasaulio slèpinius, tapusius atminties dalimi. „Mano pirmieji įspūdžiai, ar tai būtų snieguolès pavasarị, ar mažas upeliūkštis 
Šilutèje, susiję su Lietuva“, - kalbėjo viename naujausių interviu, liudydama atminties pastovumą [3].

Lietuvoje išleistos jau keturios A. Gustas poezijos knygos: Briedžiai mano broliai (1983), Eileraščiai. Proza. Piešiniai / Gedichte. Prosa. Zeichnungen (1994), Jetzt: Gedichte und Zeichnungen / Dabar: eilèraščiai ir piešiniai (1998), Dviese apie meilę (kartu su Juliumi Keleru, 2014), dar viena dvikalbė knyga pasirodė Vokietijoje - Symbiosefrauen / Simbiozés moterys (1993). Šiuose rinkiniuose poetė atsiskleidžia ịtaigia moteriškumo refleksija, meilès ir atsidavimo tema, kurią papildo savo pačios piešiniais-iliustracijomis. Nemažiau reikšminga poetinei A. Gustas kūrybai yra gimtinès, namų tema, pratęsiama tapybos darbuose, kurie eksponuoti Lietuvos galerijose. Ypač svarbią vietą užima poetinis „Vaikystès“ ciklas, nuo kurio rinktinèse Briedžiai mano broliai ir Eilèraščiai. Proza. Piešiniai / Gedichte. Prosa. Zeichnungen prasideda pažintis su šios vokiškai rašančios lietuvès kūryba. Vertèjo V. Karaliaus liudijimu, toks eilèraščiu išdèstymas buvo pasiūlytas pačios autorès $[8,105]$.

Jau pirmuoju „Vaikystès“ ciklo eilèraščiu poetè kalba apie namus ir visą jų pasaulį:

Aš gimiau

kovo diena 1932-aisiais

Karceviškiai vadinosi kaimas $[5,6]$.

Šis liudijimas yra tarsi priminimas sau pačiai gimtosios vietos vardo - juk rašoma jau esant toli nuo jos, negimtąja vokiečių kalba. Eilèraštyje minimi artimiausi žmonès: motina, tèvas, senelè, senelis, - jaučiamas jų buvimas kartu, globa:

mane isupusi

i skepetas

senele

dékojo Dievui $[5,6]$.

Kartu nuo šios globiančios šeimos yra neatsiejamas ir gamtos pasaulis, jungiantis dangaus ir žemès sferas: „virš kaimo snigo“, „užpustyti / buvo keliai“ $[5,6]$.

Vaizduotèje siekiama atgaivinti ir tai, ko neįmanoma atkurti, kitų regimybė tampa sava, asmenine, vidine regimybe, todèl kalbama ir apie pačią save, dar kūdikį:

buvo tada

mano dienos

ramios kaip egles

gražios kaip skujos $[5,7]$.

Poetè savo vaikystei apibūdinti atranda gamtiškus analogus, gamta įsirašo ị jos pasaulị kaip neatskiriama savasties dalis.

Kituose ciklo „Vaikyste““ eilèraščiuose išnyra konkrečios tapybiškos detalès, sukuriančios autentiškos patirties nuojautą:

\section{kartais}

nešiojo senelè

suknia papuošta

bulvių žiedais $[5,8]$.

Arba:

mano senelis

buvo tvirtas

jis nešiojo sunkius miltų maišus $[5,9]$. 
Kita vertus, šitas gyvas regejjimas suvokiamas jau kaip praeitis: pabrèžiama „buvo“. Tai, kas buvo, išnyra, pasirodo, tačiau ne kaip tikrovè, o kaip praeities atgarsis, „aidas mūsų kūne“.

Eilèraščiuose vaikas ir jo pasaulis sutampa su gamta, pasiduoda jos ritmui, nèra jokio skirtumo tarp žmogaus ir kitos esaties:

mèlynès

buvo mano seserys

samanos

$\dot{e} d \dot{e}$ iš mano delno $[5,25]$.

Taip poetiškai perteikiamas vaiko sutapimas su savo aplinka, atsivèrimas būties fenomenams. Tokị patyrimą raiškiai atskleidžia M. Merleau-Ponty, cituodamas dailininko André Marchando užrašus: „Miške aš dažnai jausdavau, jog tai ne aš žiūriu į mišką. Tam tikromis dienomis jausdavau, kad tai medžiai žiūri ị mane, tai jie man kalba..." [10, 58]. Galima tarti, kad A. Gustas poetinis pasaulis yra būtent toks atsivèrimas būčiai per vaiko, atviro viskam, patirtị.

Ypač svarbi visų šių tekstų, skirtų vaikystei, nuotaika. Tai nèra šaltas stebejjimas iš šalies, - tai šiltas, jaukus žvilgsnis. Bet ne idiliškas, o priimantis visa, ką duoda gyvenimas, netgi mirtị:

dabar jis guli

Šilutès žemèj

lietuviška saulè

šildo jo kapa

o žiema

Šilutès sniegas

švelniai apglébia seneli $[5,9]$.

Sunkumai, skausmas, kančia, mirtis nèra ištrinami iš gyvenimo. Atsisveikinimas su vaikyste taip pat suvokiamas kaip būties tapsmo dalis:

neša Šy $\check{\text { ša }}$

kitas vilnis

o Šilutès gatvèse

žaidžia kiti vaikai $[5,31]$.

Vaikystès prisiminimai išauga iš įtampos tarp čia, dabar ir ten, iš praeities atsiminimų. Pripažistamas erdvès nuotolis: „toli / nuo čia“ ir laiko atstumas: „senose nuotraukose / gelstančią“ $[5,36]$. Vis dèlto siekiama sugrịžti, pajausti, prisiliesti, pamatyti. Būtis atsiveria „už atsiminimų tvoros“ [5, 30], patys atsiminimai, anot poetès, „liuoksi“ [5, 45]. Taigi nèra paprasta sugrịžti ị tai, kas jau yra praeitis, tik kūno patirtis, buvusi regimybè padeda atkurti praejusių dienų šviesą.

Rinkinyje Jetzt: Gedichte und Zeichnungen / Dabar: eilèraščiai ir piešiniai poetè imasi reflektuoti šią praeities ir dabarties perskyrą. Viena vertus, savo dvigubą tapatybę A. Gustas suvokia kaip dovaną: „esu toji Berlyne / su sapno gūsiais iš Lietuvos“ [6, 81]. Kita vertus, tai iššūkis rizikuojant visko netekti:

lietuviška vaiko role

vokiška moters role

parazitine sąmoné

nesutampu su niekuo

lyg ritmas pingpongo $[6,89]$. 
Vokiškame teksto variante tas „niekuo“ yra apibrèžiamas kaip vietos gyvenime trūkumas: „damit stehe ich nun / fehl am Platz im Leben“ $[6,88]$. Taigi galima kalbèti apie ịtampos lauką tarp to, ką siekiama atsiminti, ir visa niveliuojančios sąmonès. Ypač stipriai šis atradimo ir kartu praradimo pojūtis išreiškiamas eilèraštyje apie kilmę:

dangaus kilmé

žemés kilmé

tavo kilmé mano kilmé

su kilme reikèty

nežaisti sakai tu

aš manau kitaip

pvz. dešinę koją lietuviškai

kairę koją vokiškai

taip slystu nuo aukštos kalvos

lètai į europietišką žolę $[6,85]$.

Iš pirmo žvilgsnio paprastas eilèraštis apima daug semantinių plotmių: žmogaus tapatybė yra labai sudètinga - ne vien dvasinè ir fizinè, ne vien religinè ir tautiné, sava ir svetima. Visa tai yra paties gyvenimo judesys, patirtis, kuri kelia iššǔkių, verčia pasidalyti ị du vienas kitam prieštaraujančius balsus. Tekstas baigiamas daugiaprasme slydimo metafora: tai ir svaigulio būsena, laisvės potyris, bet ir kritimas, nuopuolis - erdvės trajektorija akivaizdžiai eina žemyn, „i europietišką žolę“. Anksčiau aptartuose eilèraščiuose gyvybingas namų vaizdinys čia redukuojamas ị vienspalvę būtį.

„Aš regiu erdvę ne pagal išorinį jos apvalkalą, aš išgyvenu ją iš vidaus, esu jos apgaubtas. Pasaulis galiausiai yra aplink mane, o ne priešais mane“, - rašè M. Merleau-Ponty [10, 82]. A. Gustas pasaulèvaizdis būtent yra toks: apglèbiantis, apgaubiantis, saugantis nuo užmaršties, kuri suvokiama kaip vietos netektis.

\section{PASTANGOS ATSIMINTI SAVE MAŽĄ: VAIKO PORTRETAS}

A. Gustas paveikslų kraštovaizdis, kaip ir eilèraščiai, yra išaugęs iš stebejjimosi pasauliu. Eilèraščių cikle „Vaikystë“ matème mažą mergaitę: „tada buvau maža mergaitė / kuri su pasakom sviedinị žaisdavo" $[5,13]$, ne viename paveiksle taip pat regime tokią pat mažą mergaitę, kuri žvelgia ị mus - „Lietaus miškas“ (1983), „Žąsų mergaitë“ (1982), „Mergaite““ (1982), „Aldona“ (1981), „Mergaitè su vainiku“ (1983), „Mergaitè - paukštis“ (1985).

Bene svarbiausias yra paties vaiko žvilgsnis. Mergaitè stebi pasaulị: „Lietaus miške“ jos žvilgsnis tarsi klaustų kelio, „Žąsų mergaitë“ ir "Aldona“ vaizduoja mergaitę, ịsigilinusią i save, paveiksluose „Mergaite“ ir „Mergaitè su vainiku“ žvilgsnis nukreiptas ị tolị. Tai dailininkès bandymas atkurti save dar mažą - tas vaikas nèra išgražintas kaip lèlytè, o gyvas, judrių akių, kintančio žvilgsnio. Mergaitès veidas šviesus, ne kartą ji vaizduojama su gèlių vainiku - kaip ir eilèraštyje: „iki pasaulio krašto / driekèsi pynès / kurias iš saulučių pindavau" $[5,23]$.

Vaikystès pasaulis - toks, koks atsiskleidžia poezijoje - tarsi papildomas, praplečiamas, ivvaizdinamas pačios poetès tapytų paveikslų. Gamta čia taip pat tampa svarbiu fonu: vyrauja žalia, miško, pievos, spalva ir mėlyna - vandens, dangaus. Vaiko esatis apšviečia, sušildo, sužmogina ši pasauli, paverčia jaukiu ir kartais net pasakišku: štai paveiksle „Žąsų mergaitë“, tarsi iš pasakos, matome žąsị su karūna. Mikalojus Konstantinas Čiurlionis karūnuotus kaip pasakoje matė medžius, o štai A. Gustas - vaiko ganomą žąsį. Būtent vaikas yra tas, kurio žvilgsnis pakeičia pasaulị. 
Pasakišką vaikystès pasaulị labai raiškiai ịkūnija paveikslas „Gulbių medis“ (1974), kuris yra tarsi vaiko erdvès kvintesencija: viskas yra judejjime, kaitoje, susipinančiose formose. Ir kartu šis kone siurrealistinis kraštovaizdis yra labai lietuviškas: vyrauja žalsvos, melsvos, gelsvos spalvos - vèlgi kaip lietuviško peizažo dominantės, atrastos dar M. K. Čiurlionio pastelèse. Ittaigi ir ịtikinanti A. B. Willeke ịžvalga randant A. Gustas kūrybos paralelių su Marco Chagallo folkloriniu siurrealizmu (folk-surrealism) [11] - tik šikart ịsiterpia ne žydų tautinis paveldas, o archajiškas lietuvių kultūros klodas su pasakomis apie gulbes, medžius, jūras, karalaites ir pan.

Viena vertus, A. Gustas paveikslų gamtovaizdis nèra konkretizuotas - ne taip, kaip eilèraščiuose, kur minimi Karceviškiai, Šilutè, Šyša, Nemunas, Šešupè. Kita vertus, neapleidžia jausmas, kad čia yra Lietuva - pievos, miškai, upès vingis. Visa tai perteikiama spalvų dèmėmis - tarsi iš atminties išnyrančiais Lietuvos kraštovaizdžio ženklais. Visus šiuos paveikslus dailininkẻ kūrè jau praejjus nemažai laiko nuo pasitraukimo iš gimtinès - tai išties būta tik „regimybès šifrų“, perteiktų simboline spalvų kalba. Beje, viename paveiksle tas spalvinis simbolizmas ypač krenta ị akis - tai „Svajonių scena III“ (1977); jame žmonès tarsi papuošti tautinès vèliavos spalvomis: svarbios geltonos, raudonos, žalios spalvinès dèmès. Paveiksle matomi žmonès yra tarsi bangos nešami - vaizduojama pati būtis, kuri skleidžiasi per tautą, jos gyvybę ir savastį.

M. Merleau-Ponty yra rašęs: „Tai, kas vadinama ịkvėpimu, suvoktina paraidžiui: iš tiesų yra būties įkvėpimas ir iškvėpimas, būties alsavimas; veiksmas ir kęsmas atskiriami taip sunkiai, jog nebežinia, kas regi, o kas regima, kas tapo, o kas tapoma“ [10, 58]. A. Gustas ne tik savo eilèraščiais, bet ir paveikslais sieke įsijausti į tą būties tapsmą, patirtị, užfiksuotą prisiminimuose apie vaikystę Lietuvoje.

\section{IŠVADOS}

A. Gustas poezija ir tapyba išauga iš vieno pagrindo: ịsigilinimo ị patirtis, kurios išgyventos Lietuvoje, vaikystès namuose, gimtos aplinkos apsuptyje. Eilèraščiuose atsiskleidžia vaiko artumas visiems - tèvams, seneliams, žolei, paukščiams, medžiams, dangui... Maža mergaitè džiaugiasi savo pasauliu ir susilieja su juo. Kita vertus, jaučiama įtampa tarp buvo ir yra, fiksuojama praeinamybė: laiko matmuo poezijoje labai svarbus. O tapyboje viskas atrodo tarsi yra „dabar“: tai ir prisiminimai, kurie leidžia išgriebti iš atminties spalvas, kontūrus, peizažo detales. Šis pasaulis yra gyvas, judantis, šiltas ir kartu pasakiškas vaikystės slëpinys. Dailininkè dažniausia renkasi žalią, mėlyną ir gelsvą spalvas - kaip nuorodą ị to pasaulio pilnatviškumą, tarsi susijungia dangaus ir žemès sferos. Kartu šis pasaulis nèra idiliškas: tai regimybė iš vidaus, sušildyta autentiškų vaikystès prisiminimų. A. Gustas yra ta regètoja, kuri, atmesdama išankstini žinojimą, bando užčiuopti tai, kas jai pačiai atsiveria kaip esmè, ką yra patyrusi savo akimis ir išsaugojusi nuo vaikystės iki brandaus amžiaus.

Gauta 20151105

Priimta 20160913

\section{Šaltiniai ir literatūra}

[1] ALAUŠIUS [Juozas Girnius]. Aldona Gustaitè. Vokiečių poetė lietuvaitè. Aidai, 1969, Nr. 9 [žiūrèta 201506 10]. Prieiga per internetą: http://aidai.eu/index.php?option=com_content\&vie$\mathrm{w}=$ article\&id=4462:pa\&catid=284:196909\&Itemid=321.

[2] BALIUKONYTÉ, Ona. Aldonos Gustas pasaka. Literatūra ir menas, 1984 sausio 14, p. 5.

[3] BARNIŠKIENÉ, Sigita. Aldona Gustas: „esu toji Berlyne / su sapno gūsiais iš Lietuvos“. 
Literatūra ir menas, 2014 vasario 21, Nr. 3462 [žiūrèta 201505 12]. Prieiga per internetą: http:// literaturairmenas.lt/2014-02-21-nr-3462/1536-pokalbiai/2402-aldona-gustas-esu-toji-berlyne-susapno-gusiais-is-lietuvos.

[4] GEDA, Sigitas. Kažkas iš mūsų pramotès. Šiaurès Atènai, 1995, vasario 25, p. 14.

[5] GUSTAS, Aldona. Briedžiai mano broliai. Iš vokiečių kalbos vertẻ V. Karalius. Vilnius: Vaga, 1983. $110 \mathrm{p}$.

[6] GUSTAS, Aldona. Jetzt: Gedichte und Zeichnungen / Dabar: eilèraščiai ir piešiniai. Iš vokiečiu kalbos vertė G. Bartelt, V. Karalius, V. Saunoriūtè-Muschick. Vilnius: Baltos lankos, 1998. 102 p.

[7] KUBILIUS, Vytautas. Paprastas ir jaukus kalbėjimas. Pergalè, 1984, Nr. 3, p. 181-182.

[8] KARALIUS, Vytautas. „Apsèti lauką eilèraščiais... “ Iš: GUSTAS, Aldona. Briedžiai mano broliai. Iš vokiečiu kalbos vertè V. Karalius. Vilnius: Vaga, 1983, p. 101-105.

[9] MAZILIAUSKAS, R. E. Panas lietuviškose samanose. Aldona Gustas ir jos kūryba. Septintoji pradalgé. Literatūros metraštis, 1970, p. 304-319 [žiūrèta 201506 10]. Prieiga per internetą: http:// www.epaveldas.lt/vbspi/biRecord.do?biRecordId=35271.

[10] MERLEAU-PONTY, Maurice. Akis ir dvasia. Iš prancūzų kalbos vertè A. Sverdiolas. Vilnius: Baltos lankos, 2005. $116 \mathrm{p}$.

[11] WILlEKE, Audrone B. Airy Cages: The Poetry of Aldona Gustas. Lituanus, 1981, Vol. 27, No. 4 [žiūrèta 201504 12]. Prieiga per internetą: http://www.lituanus.org/1981_4/81_4_07.htm.

AURELIJA MYKOLAITYTE்

\title{
Symbolic landscape in Aldona Gustas' poetry and painting
}

\author{
Summary
}

Aldona Gustas (b. 1932) is a German poetess and painter of Lithuanian descent. Her creative work, both poetry and painting, can be recognized from the imaginary landscape of Lithuania that she remembers from her childhood. In her poetry, this landscape is described by concrete names of Lithuanian rivers, locations, and towns (for example, Šyša, Šešupe, Nemunas, Karceviškiai, Šilutè, Vilnius). Meanwhile, although her paintings are generalized, the shapes and colours in them allow us to recognize the landscape of Gustas' native land. Her paintings remind of her childhood: perhaps the most notable characteristic of her landscape paintings is the sense of fairy-tales, dreams, and beauty. We see the blue and the green of nature: seas, rivers, and forests. A little girl is in the centre of this world. In Gustas' poems written in the first person singular, we can hear the sincere voice of the girl who is an interpreter of the Lithuanian world. The paintings also show the world of that fair-haired girl. Her fixed look into the distance - investigating, waiting, and searching - is especially important. Gustas' poems and paintings express different aspects of her experience, but at the same time these two media are mutually complementary. Such is the world of her imagination: the poetess-cum-painter tries to convey her own memories and her own experience of Lithuanian landscape engraved in her poetic soul.

Keywords: landscape, poetry, painting, memory, imagination 